\title{
Blended Learning Perception among Undergraduate Engineering Students
}

\author{
http://dx.doi.org/10.3991/ijet.v11i01.4901 \\ T.I. Krasnova, I.S. Vanushin \\ National Research Tomsk Polytechnic University, Tomsk, Russia
}

\begin{abstract}
Technology is constantly evolving in more sophisticated forms giving new opportunities for educators to transfer learning into virtual space. New educational technology trends are associated today with blended learning where traditional methods of teaching merge with online sessions. Blended learning with its learner-centered approach has a potential to enhance the quality of teaching and learning. Russian higher institutions embrace this technology as a strategy to engage and motivate students and thereby augment the learning process. The paper studies students' engagement and satisfaction with the online courses and their overall perception from learners' perspective. The findings could serve as a reference point to promote online courses and to achieve considerable educational benefits.
\end{abstract}

Index Terms-Blended learning, Moodle, online course, student satisfaction.

\section{INTRODUCTION}

Advancement in technology predestines not only the country economy but has a great impact on education as well. A paradigm shift is needed towards appropriate implementation of technology tools to enhance teaching quality and augment the learning process. Within the scope of the new paradigm students shouldn't be only given some extent of knowledge, they should be taught different ways of thinking, developing creativity, finding new solutions without assistance, performing well in standard and nonstandard situations. E-learning technologies transform ordinary transfer of knowledge into collaborative learning, help to bring together the positions of instructors and students, activate their creative potential [1]. It is mostly beneficial as it provides a wider vision, taking student diversity and the dynamic nature of the course into consideration [2].

The most popular e-learning technology, capable of solving multiple tasks, is blended learning which is often thought as a way how both educators and students can meet their teaching and learning needs. This technology is profoundly transforming education, training and learning, while engaging and motivating students all over the world [3].

Widespread integration of blended learning is evident and long expected in Russia. A rapid rise of blended learning is derived from the desire to make use of new technology trends in educational context. Blended learning takes the best from two forms of teaching combining effective face-to-face teaching techniques with online interactive collaboration. The authorities of National Research Tomsk Polytechnic University (TPU) launched a campaign for integrating blended learning in all academic disciplines. Foreign language teachers were among the first who started using blended learning method to create their courses and increase students' outcomes.

The online course content is usually exposed via an online platform, in our case Moodle, providing not only resources storage but interaction between the participants and even the development of learning community. Students access learning materials and assignments from any convenient place and at any convenient time. Online course is easy to use and has a wide range of activities to make the process of learning a language entertaining while still offering intensive practice.

\section{ONLINE COURSE CHARACTERISTICS IN A BLENDED LEARNING MODEL}

Learning foreign languages constitutes an invaluable part of an educational curriculum at TPU. In order to graduate from the University with a Bachelor's degree, students need to study a foreign language for three years. Language courses at TPU are often accompanied with online self-regulated practice based on a Moodle platform. Moodle is a Learning Management System (LMS) and is one of the most effective learning tools for educational institutions as it helps create engaging online language learning activities. Moodle supports a learning model where a tutor acts as a course moderator. An online course on Moodle provides an individual approach to each student by creating a virtual environment for group collaboration.

One of the biggest advantages of using a Moodle for online course delivery, rather than a collection of disparate online tools, is that everything is in one place, and learners' work, grades and contributions can be easily monitored. Being in one place (in this case, in one website) it is also easier to build a sense of online community among learners in LMS than by, say, an email [4].

There are many advantages of using LMS in a learning process. To begin with, the source is available to everyone at all times. It allows training according to the 24/7/365 principle; which means that students can learn 24 hours a day, 7 days a week and 365 days a year. The lectures and assignments are available at any time and it is for participants to decide how fast they want to go through the course. Being in an online environment, students can work not only with course materials but also access any web resource. 
Moodle has many attractive features, because it provides:

- ease of use - you don't need any programming skills;

- access to resources via the web;

- interaction between learners and tutors;

- collaboration among learners;

- independent learning pathways;

- learner tracking;

- feedback on tasks;

- secure environment;

- automatic backup [5].

The course "General English Blended Course" for firstyear students studying at the Institute of Cybernetics has face-to-face format and supported with the online materials, discussions and activities. The online course has become an important course element when students and tutors are in close cooperation even when they do not see each other. In this learning process students spend some time to independently assimilate learning materials, pass tests, fulfill different assignments under tutoring and interact with other students of the virtual environment.

Looking at the course statistics we can assume that some students work and interact more online than in faceto-face sessions; however there are some students who interact at minimum only in the frameworks of the teacher's instruction or even less. One more thing can be clearly observed from the statistics: online environment is especially favourable for discussions when students who usually hide behind their group-mates backs during classroom discussions can also participate. Unfortunately simple observations do not give the full picture of students' attitudes to the online course.

\section{Methods And Data AnAlysis}

To understand students' perception of online courses a questionnaire was conducted in 5 language groups in April, 2015, in which 46 students took part. The participants were undergraduate students of TPU Cybernetics Institute. They were enrolled to the course "General English Blended Course" from the beginning of the academic year. The main questions underlying the survey were:

- What do students think about online courses?

- What can be done to improve students' satisfaction with online courses?

Students' perception of online courses can be analyzed through frequency of using some functional elements of the course, usability of online platform, and usefulness of online courses [6]. Therefore the survey contained the checkboxes developing the ideas above. At the end the participants had to write a detailed answer expressing their overall attitude to online courses.

\section{RESULTS}

At first the frequency of using the online course "General English Blended Course" was investigated. The results are shown in Table 1.

As we see from Table 1 the most frequent activity on Moodle is 'taking quiz tests' (92,8\% 'Very often') which is explained by the fact that the online course content contains mostly quiz tests with deadlines and students perform them regularly. They don't usually need to download course materials because they always have access to them online that is why we see that only $35,7 \%$ of students download them 'Very often' and even there are those who never do this $(28,5 \%)$. Students actively check course announcements and their grades; they need to keep track of the course and are really interested in the feedback about their quiz tests and assignments. Main assignments and online discussions occur once a month so we see the highest percentage in the column 'Sometimes'. There are no students who never participated in online discussions, didn't submit any assignment or take any quiz test. This fact indicates students' high involvement in the learning process online.

Ease-of-use factor was analyzed with the help different options to be ranged from 5 (the best) to 1 (the worst). Table II reflects mean values of each option.

The highest mean values are 'Ease in logging in' $($ mean $=4,6)$, 'Organization of materials' (mean=4,4) and 'Ease of access to materials' (mean=4,2). We can assume that students don't usually have technical problems with logging in Moodle and it is really available at any time. Students like the organization of materials probably because it is very simple and structured. The same is with the access to materials; reference materials are never hidden even after the module completion. 'Ease of assignment submission', 'Time required to learn the system' and 'Visual appearance' come next but still have quite high mean value. 'Participation in forums' and 'Intuitive navigation' didn't satisfy all students. 'Search tool' was ranked the least (mean=3,3). Some students confessed that they didn't even see it but still didn't need this tool.

Table III shows the mean values of usefulness factors.

TABLE I.

FREQUENCY OF USING THE ONLINE COURSE

\begin{tabular}{|l|c|c|c|c|}
\hline \multicolumn{1}{|c|}{ Activity } & Very often & $\begin{array}{c}\text { Sometimes } \\
\text { (monthly use) }\end{array}$ & Rarely & Never \\
\hline $\begin{array}{l}\text { Downloading } \\
\text { course materials }\end{array}$ & $35,7 \%$ & $28,5 \%$ & $7,3 \%$ & $28,5 \%$ \\
\hline $\begin{array}{l}\text { Checking course } \\
\text { announcements }\end{array}$ & $50 \%$ & $28,5 \%$ & $21,5 \%$ & $0 \%$ \\
\hline $\begin{array}{l}\text { Checking course } \\
\text { grades }\end{array}$ & $42.9 \%$ & $35,7 \%$ & $7,1 \%$ & $14,3 \%$ \\
\hline $\begin{array}{l}\text { Submitting assign- } \\
\text { ments }\end{array}$ & $7 \%$ & $71,4 \%$ & $21,6 \%$ & $0 \%$ \\
\hline Taking quiz tests & $92,8 \%$ & $1,2 \%$ & $0 \%$ & $0 \%$ \\
\hline $\begin{array}{l}\text { Participating in } \\
\text { online discussions }\end{array}$ & $14,3 \%$ & $57,1 \%$ & $28,6 \%$ & $0 \%$ \\
\hline
\end{tabular}

TABLE II.

USABILITY OF THE ONLINE COURSE

\begin{tabular}{|l|c|}
\hline \multicolumn{1}{|c|}{ Factor } & mean \\
\hline Ease in logging in & 4,6 \\
\hline Ease in assignment submission & 4,2 \\
\hline Ease of access to materials & 4,6 \\
\hline Time required to learn the system & 4 \\
\hline Organization of materials & 4,4 \\
\hline Intuitive navigation & 3,7 \\
\hline Ease in forums participation & 3,6 \\
\hline Visual appearance & 4,1 \\
\hline Search tool & 3,3 \\
\hline
\end{tabular}




\section{Blended Learning Perception among Undergraduate Engineering Students}

TABLE III.

USEFULNESS OF THE ONLINE COURSE

\begin{tabular}{|l|c|}
\hline \multicolumn{1}{|c|}{ Factor } & mean \\
\hline Enhances finding necessary information & 4,2 \\
\hline Has a positive impact on learning & 4,2 \\
\hline Helps to keep up with the coursework & 4,4 \\
\hline Helps to organize the study & 3,9 \\
\hline Helps to keep up when a class was missed & 3,5 \\
\hline Promotes the group work & 3,4 \\
\hline Takes up a lot of time & 2,9 \\
\hline
\end{tabular}

'Helps to keep up with the coursework' (mean=4,4) was recognized the most useful option of the online course. Next students mentioned 'Enhances finding necessary information' (mean=4,2) and 'Has a positive impact on learning' (mean=4,2). Factors with the lowest mean values are 'Promotes the group work' $($ mean=3,4) and 'Takes up a lot of time' (mean=2,9).

The survey showed that most of students are satisfied working in online environment, but some students still prefer face-to-face instruction for group activities. All in all they find Moodle more convenient and contrast it with loads of paper assignments they had to perform in the past. One student called this online course 'a step forward' and didn't want to return to paper work.

As a benefit students mentioned the abundance of listening and video activities that can't be present in such amounts in ordinary lessons as they require a lot of time and can't fit the frameworks of face-to-face sessions. This became a real treasure for students zealous for realistic and stimulating dialogues and monologues featuring people in everyday situations.

Some students pointed out a great variety of interactive tasks developing grammar and vocabulary skills. Second language acquisition research has shown that the grammar of the second language does not develop unless an effort is made to continuously analyze, learn and practice it. It is proved that repetition is very important in language learning and a blended course has a unique way to recycle the language of the lesson during online practice. This aims to reinforce the understanding of a language and how it is used through real-world tasks. As a result in the online environment students have more opportunities to explore the language.

Immediate feedback to tests attracts all students; they see their grade and analyze the mistakes right away. They recognize their progress in the target language, understand how much they achieved and what areas need further practice. The achievement they make is can become a very motivating tool.

Despite the satisfaction with online course students realize the importance of face-to-face meetings and want to combine online course with traditional lessons.

\section{CONCLUSION}

Blended learning has become increasingly popular in teaching foreign languages. Blended learning can be very timesaving and provides convenience and flexibility of learning. It has a tremendous potential in teaching foreign languages as it offers an opportunity to integrate innovative and technological advances of online learning with interaction and participation of the best traditional practices.

The success of blended learning courses is strongly dependent upon the students' perception. In this study we tried to investigate students' perception of online courses that usually accompany face-to-face instruction in blended learning. The results indicated that students' satisfaction with the online was mainly affected by convenience, clarity of design, ease-of-use and flexibility of learning. The findings of this study could have direct implications for the creation, development, and delivery of online courses in blended learning.

\section{REFERENCES}

[1] Krasnova, T. A Paradigm Shift: Blended Learning Integration in Russian Higher Education. Procedia-Social and Behavioral Sciences, vol. 166, 2015, pp. 399-403. http://dx.doi.org/10.1016/ j.sbspro.2014.12.543

[2] Danielewicz-Betz, Anna, \& Tatsuki Kawaguchi. "Gaining Handson Experience via Collaborative Learning: Interactive Computer Science Courses." International Journal of Emerging Technologies in Learning (iJET) [Online], vol. 10, n.3 2015, pp. 34-40. http://dx.doi.org/10.3991/ijet.v10i3.4510

[3] Nafukho, F. M. (Ed.). Handbook of Research on Innovative Technology Integration in Higher Education. IGI Global, 2015. http://dx.doi.org/10.4018/978-1-4666-8170-5

[4] Hockly, N. \& Clandfield, L. Teaching Online: Tools and Techniques, Options and Opportunities, Delta Publishing, 2010.

[5] Stanford, Jeff. Moodle 1.9 for second language teaching. Packt Publishing Ltd, 2009.

[6] Wang, Y. H., Tseng, Y. H., \& Chang, C. C. "Comparison of Students' Perception of Moodle in a Taiwan University against Students in a Portuguese University." Advances in Web-Based Learning-ICWL 2013. Springer Berlin Heidelberg, 2013. pp. 7178.

\section{AUTHORS}

T. I. Krasnova is with the National Research Tomsk Polytechnic University, Tomsk, Russia (e-mail: krasnova@tpu.ru).

I.S. Vanushin is with the National Research Tomsk Polytechnic University, Tomsk, Russia (e-mail: iwouldnot@ya.ru).

Manuscript received 28 July 2015. Published as resubmitted by the authors 26 December 2015. 